\title{
Coronavirus: vencer la epidemia dependerá de la vocación sanitaria y la responsabilidad social de la ciudadanía
}

\section{Coronavirus: Winning the battle against the epidemic will depend on health education and the social responsibility of citizens}

Milward Ubillús ${ }^{1, a}$



Como era de esperarse, más temprano que tarde la pandemia de la COVID-19, llegó a Huánuco y, como en toda comunidad, ha causado una histeria colectiva, expresada en el temor y la desesperación de enfrentarse, cara a cara, a la muerte. A pesar de las acciones y disposiciones desesperadas dictadas por un gobierno, cuyo sector de salud tiene experiencias demostradas en anteriores epidemias de las que salió bien librado; como el cólera que, en el año 1991, nos cobró 323000 afectados y 2900 fallecidos, mucho menor que en otros países ${ }^{(1)}$.

De igual modo la epidemia de la enfermedad de Carrión que, entre el 2003 y el 2005, afectó a 10000 personas aproximadamente; la epidemia de la influenza AH1N1 que, en el 2009, causó 9000 infectados aproximadamente, falleciendo alrededor de 190 personas; y la última epidemia de dengue en el 2017, con casi 70000 afectados (2); igualmente nos sorprende con un sistema de salud debilitado, ineficiente y desbordado. Sin embargo, debo resaltar que ante una epidemia ningún sistema sanitario de ningún país del mundo, por más eficiente, sólido y preparado que sea, puede enfrentar y superar la crisis de manera unilateral, sin la participación adecuada y el apoyo de la comunidad.

En este sentido, el éxito de superar la epidemia de la COVID-19 en el Perú y particularmente en nuestra Región de Huánuco, va a depender de la capacidad con la que el sistema sanitario cumpla su rol y en gran medida en que nuestra población éste preparada, conozca cómo actuar ante ésta nueva enfermedad colectiva y, sobre todo, en asumir y cumplir la responsabilidad social que le toca a cada persona de manera individual. Esta nueva patología poblacional que amenaza a la salud pública y a la salud global tiene sus particularidades como toda pandemia. A diferencia de otras epidemias, su trasmisión se da de dos formas: de manera directa, de persona a persona, y también de forma indirecta, a través de objetos contaminados; es decir, de objeto a persona, siendo ambas formas igual de eficientes para el virus en contra de los seres humanos.

La transmisibilidad del microbio es baja en personas asintomáticas, pero se da y el período aproximado de latencia es de dos semanas; lo que ha sido establecido a través de los estudios epidemiológicos y clínicos. Por lo que es importante la vigilancia en personas que han tenido contacto con casos positivos o con contactos sospechosos, aun cuando no presenten ningún síntoma respiratorio. Las personas que tengan sintomatología respiratoria y hayan estado en contacto con casos positivos o en zonas donde circula el virus, deben acudir 
al sistema de salud para los estudios de descarte correspondiente ${ }^{(3)}$; mientras aquellos que tengan cualquier síntoma de dificultad para respirar, sin importar la causa, deben acudir de inmediato a ser atendidos en el establecimiento que le corresponde. Según la bibliografía científica, en el $80 \%$ de la población, esta epidemia pasará inadvertida o con síntomas leves. En el $15 \%$ se presentará con complicaciones que serán resueltas por el sistema de salud, pero en un $5 \%$ aproximadamente si será muy grave y complicada, pudiendo terminar lamentablemente en el fallecimiento. En este último grupo está la población en mayor riesgo que son las personas que padecen enfermedades crónicas, los adultos mayores y las gestantes; por lo que es precisamente a ellos a quienes tenemos que cuidar.

Ese $80 \%$ que probablemente no tendrá mayor problema en el que están los niños (felizmente), los jóvenes y adultos, quienes son los que deben demostrar su compromiso social y su solidaridad colectiva, cumpliendo con mayor énfasis las recomendaciones y las medidas de prevención que dicta la autoridad sanitaria. Protegiendo a nuestros ancianos y población vulnerable. El gobierno ha dictado severas medidas, tarde o temprano ya no importa; ahora debemos cumplirlas. Se ha declarado una "cuarentena social" con todas las medidas que buscan que estemos en casa, que no participemos de eventos de conglomeración y de grupos; estamos ejerciendo una medida de protección sanitaria pública y es la que mejor resultado ha demostrado en ésta pandemia. Usemos la experiencia de los países que nos llevan algún tiempo la delantera en su propagación. China, Italia y España son espejos de los cuales debemos aprender; sin embargo, sin la vocación sanitaria y la responsabilidad civil de nuestros compatriotas, los costos van a ser muy altos. Lo que va de la cuarentena en Perú nos deja algunas conclusiones: 1. Las Fuerzas Armadas y la Policía Nacional del Perú deberían ejercer con mayor rigor su autoridad. 2. Gran parte de la población peruana no respeta absolutamente a nada ni a nadie. 3 . Falta mucha educación a nuestro pueblo. 4. Los extranjeros hacen lo que les da la gana. Cumplamos con lo que nos toca hacer. Invoco a su responsabilidad social y solidaridad.

\section{REFERENCIAS BIBLIOGRÁFICAS}

1. Maguiña C, Seas C, Galán E, Santana JJ. Historia del cólera en el Perú en 1991. Acta méd. peruana [Internet] 2010 Jul; 27(3): 212-217 [consultado 2020 Abr 23] Disponible en: http://www.scielo.org.pe/scielo.php?script=sci_ arttext\&pid=S1728-59172010000300011\&Ing=es.

2. Centros para el Control y Prevención de Enfermedades CDC. Pandemia H1N1 del 2009 (virus H1N1pdm09). [Internet] [Consultado 2020 Enr 19] Disponible en: https://espanol.cdc. gov/flu/pandemic-resources/2009h1n1-pandemic.html.

3. Ministerio de Salud Pública y Bienestar Social de Paraguay. Plan de respuesta nacional al eventual ingreso del coronavirus (COVID-19) v1.0. [Internet] [Consultado 2020 Feb 26] Disponible en: https://www.mspbs.gov. py/dependencias/portal/adjunto/78806d-PlandeRespu estaNacionalaleventualingresodelCoronavirusV1.0.pdf 